\title{
The Neurophysiology and Pathology of Brain Zinc
}

\author{
Stefano L. Sensi, ${ }^{1,2,3}$ Pierre Paoletti, ${ }^{4}$ Jae-Young Koh, ${ }^{5}$ Elias Aizenman, ${ }^{6,9}$ Ashley I. Bush,,${ }^{7,8}$ and Michal Hershfinkel ${ }^{9}$ \\ ${ }^{1}$ Department of Neuroscience and Imaging, Molecular Neurology Unit, CeSI-Center for Excellence on Aging, University “G. d'Annunzio," Chieti 66013, \\ Italy, Departments of ${ }^{2}$ Neurology and ${ }^{3}$ Pharmacology, University of California, Irvine, Irvine, California 92697-4292, 4 Institut de Biologie de l'Ecole \\ Normale Supérieure, Ecole Normale Supérieure, CNRS UMR8197, INSERM U1024, 75005 Paris, France, ${ }^{5}$ Department of Neurology, University of Ulsan, \\ Seoul 138-736, Republic of Korea, ${ }^{6}$ Department of Neurobiology, University of Pittsburgh School of Medicine, Pittsburgh, Pennsylvania 15261, ${ }^{7}$ The Mental \\ Health Research Institute, Parkville, Victoria 3052, Australia, ${ }^{8}$ Department of Pathology, University of Melbourne, Parkville, Victoria 3010, Australia, and \\ ${ }^{9}$ Department of Morphology, Faculty of Health Sciences, Ben-Gurion, University of the Negev, Beer-Sheva 84105, Israel
}

Our understanding of the roles played by zinc in the physiological and pathological functioning of the brain is rapidly expanding. The increased availability of genetically modified animal models, selective zinc-sensitive fluorescent probes, and novel chelators is producing a remarkable body of exciting new data that clearly establishes this metal ion as a key modulator of intracellular and intercellular neuronal signaling. In this Mini-Symposium, we will review and discuss the most recent findings that link zinc to synaptic function as well as the injurious effects of zinc dyshomeostasis within the context of neuronal death associated with major human neurological disorders, including stroke, epilepsy, and Alzheimer's disease.

\section{Introduction}

Brain zinc, in its free ionic form $\left(\mathrm{Zn}^{2+}\right)$, is present within synaptic vesicles at glutamatergic nerve terminals and is synaptically released during neuronal activity. $\mathrm{Zn}^{2+}$ is also bound to metalloproteins and intracellularly mobilized upon oxidative stress. A growing and exciting body of evidence indicates that $\mathrm{Zn}^{2+}$ plays a dynamic role in both the physiology and pathophysiology of brain function.

Synaptic activation releases vesicular $\mathrm{Zn}^{2+}$, bringing its concentrations in the synaptic cleft to transiently rise. The exact amount of such release is controversial, but many laboratories have indicated (with the limitation of the current imaging techniques) that transient $\mathrm{Zn}^{2+}$ increases may reach 1-100 $\mu \mathrm{M}$ (Vogt et al., 2000; Qian and Noebels, 2005; Frederickson et al., 2006). Others have indications for lower (submicromolar) concentrations (Komatsu et al., 2005). Fuelling the controversy is the fact that measurement of actual $\mathrm{Zn}^{2+}$ levels within the synaptic cleft is technically challenging, given the short time in which the free ion is present in the synapse (Hurst et al., 2010). Some authors have alternatively suggested that the ion does not diffuse in the cleft and is actually only externalized following exocytosis. In this view, $\mathrm{Zn}^{2+}$ remains bound to the plasma membrane, forming a "veneer" on presynaptic terminals (Kay, 2003; Kay and Tóth, 2008). While this is an intriguing hypothesis, the interpretation of

Received July 7, 2011; revised Sept. 5, 2011; accepted Sept. 16, 2011.

S.L.S. is supported by funds from the Italian Department of Education (FIRB 2003, PRIN 2006). P.P. is supported by Agence Nationale de la Recherche and FRM (Fondation pour la Recherche Médicale; "Equipe FRM" grant). J.Y.K. is supported by a National Research Foundation of Korea grant (2005-0093836). A.I.B. is supported with funds from the National Health and Medical Research Council of Australia, and The Australian Research Council. E.A. is supported by NIH Grant NS043277. E.A. and M.H. are jointly supported by a grant from the US-Israel Binational Science Foundation (2007112). We are in debt to Mary Evangeline Oberschlake for the editing and critical revision of the manuscript.

Correspondence should be addressed to Stefano L. Sensi at the above address. E-mail: ssensi@uci.edu.

DOI:10.1523/JNEUROSCI.3454-11.2011

Copyright $\odot 2011$ the authors $\quad 0270-6474 / 11 / 3116076-10 \$ 15.00 / 0$ these results needs to take into account the variability in preexisting vesicular $\mathrm{Zn}^{2+}$ levels, as these are known to be affected by changes in previous synaptic activity (i.e., sensory experience), the animal age, and the methods used in the preparation of brain slices (Frederickson et al., 2006; Nakashima and Dyck, 2009). Future studies combining electrophysiology with state-of-the-art synaptic $\mathrm{Zn}^{2+}$ imaging are likely to give a more accurate description of the precise dynamics and concentrations of the ion during activity-dependent synaptic activity.

Exogenously applied $\mathrm{Zn}^{2+}$ profoundly affects the activity of glutamate, $\mathrm{GABA}_{\mathrm{A}}$, and glycine ionotropic receptors. Extracellular $\mathrm{Zn}^{2+}$ therefore is likely to be intimately linked to the balance of excitation and inhibition in the brain. Indeed following stimulation of $\mathrm{Zn}^{2+}$-containing fibers, endogenous $\mathrm{Zn}^{2+}$ has been shown to block postsynaptic NMDA (Vogt et al., 2000; Molnár and Nadler, 2001a) and $\mathrm{GABA}_{\mathrm{A}}$ (Ruiz et al., 2004) receptors. However, the modulation of postsynaptic receptors by $\mathrm{Zn}^{2+}$ is likely complex, as other investigators have failed to find effects of vesicular $\mathrm{Zn}^{2+}$ on $\mathrm{GABA}_{\mathrm{A}}$ receptors (Molnár and Nadler, 2001b) and neuronal excitability (Lopantsev et al., 2003; Lavoie et al., 2007).

More recent findings also indicate that synaptically released $\mathrm{Zn}^{2+}$ activates a specific metabotropic $\mathrm{Zn}^{2+}$-sensing receptor (Fig. 1B) (Besser et al., 2009; Chorin et al., 2011). $\mathrm{Zn}^{2+}$ can flux into neurons and be taken up in organelles such as mitochondria (Sensi et al., 2000; Caporale et al., 2009; Dittmer et al., 2009), and recent evidence in non-neuronal cells indicates that some uptake might occur in the endoplasmic reticulum and the Golgi apparatus (Qin et al., 2011) as well. Neurons also keep cytosolic $\left[\mathrm{Zn}^{2+}{ }_{\mathrm{i}}\right.$ levels very low by using several ZnT transporters (the SLC30 family), ZIP transporters (the SLC39 family), and $\mathrm{Zn}^{2+}$ buffering metallothioneins (MTs) as well as other transporters such as a putative $\mathrm{Na}^{+} / \mathrm{Zn}^{2+}$ exchanger (Sensi et al., 2009).

On the dark side, $\mathrm{Zn}^{2+}$ is also a potent neurotoxin (Fig. 2) involved in variety of conditions that have been associated with 

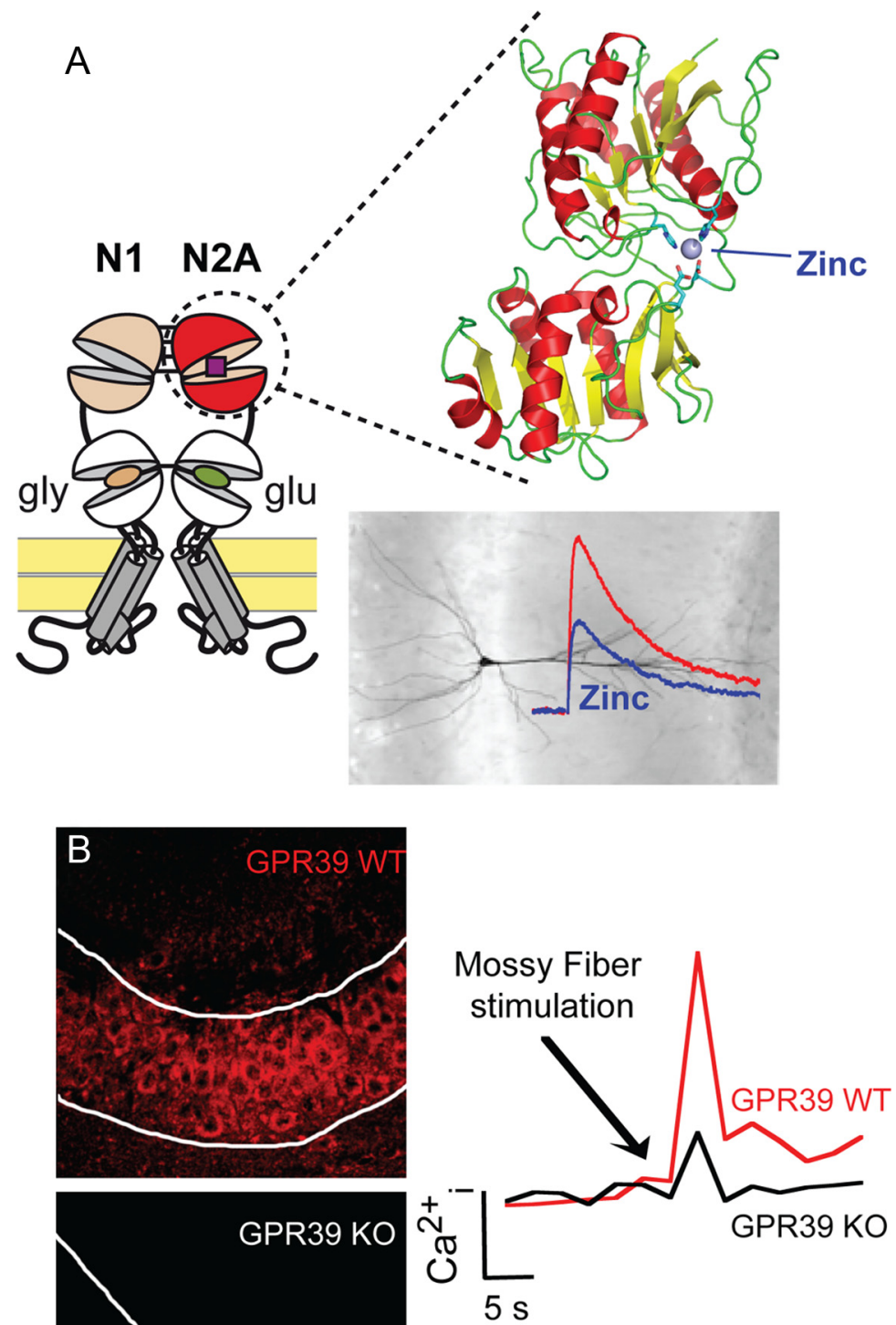

Figure 1. $\quad \mathrm{Zn}^{2+}$ and synaptic function. $\boldsymbol{A}$, A high-affinity " $\mathrm{Zn}{ }^{2+}$ sensor" in NMDA receptors. NMDAR subunits contain in their extracellular region a tandem of clamshell-like domains, the N-terminal domain (NTD) and the agonist-binding domain, which is directly connected to the transmembrane pore region. In the GluN2A subunit, the NTD forms a discrete high-affinity $\mathrm{Zn}^{2+}$ binding site that underlies allosteric inhibition of NMDAR-mediated synaptic currents by nanomolar $\mathrm{Zn}^{2+}$ concentrations. $\boldsymbol{B}$, Synaptic $\mathrm{Zn}^{2+}$ activates a specific $\mathrm{mZnR}$. Synaptic $\mathrm{Zn}^{2+}$ released from the mossy fibers activates metabotropic $\mathrm{Ca}^{2+}$ release via the $\mathrm{ZnR}$. The expression of GPR39 (left panel) and synaptic $\mathrm{Zn}^{2+}$-dependent $\mathrm{Ca}^{2+}$ release (right panel) are eliminated in the CA3 pyramidal cell layer in GPR39 K0 mice. The activity of the $\mathrm{mZnR}$ triggers phosphorylation of ERK1/2 and regulation of $\mathrm{Cl}^{-}$transport, which lead to increased inhibitory drive.

excitotoxicity, including ischemia, epilepsy, and brain trauma (Sensi et al., 2009). $\mathrm{Zn}^{2+}$ promotes both neuronal and glial death in vitro and in vivo (Choi et al., 1988). Landmark in vivo studies have shown that the transsynaptic movement of $\mathrm{Zn}^{2+}$, a process also called " $\mathrm{Zn}^{2+}$ translocation," plays a role in neuronal death associated with transient global ischemia (TGI) (Tønder et al., 1990; Koh et al., 1996). However, more recent evidence indicates that $\mathrm{Zn}^{2+}$ mobilization from intracellular pools is also a crucial contributor to neuronal injury (Aizenman et al., 2000; Lee et al., 2000, 2003; Hwang et al., 2008).

Finally, $\mathrm{Zn}^{2+}$ can play an important role in the development of Alzheimer's disease (AD). The cation is a key component of amyloid plaques, and it is now suggested that $\mathrm{Zn}^{2+}$ deregulation in the brain facilitates the synaptic deficits and cognitive decline observed in $\mathrm{AD}$, while restoring brain $\mathrm{Zn}^{2+}$ homeostasis may represent an important and novel therapeutic avenue (Corona et al., 2010) (Fig. 3A).

In this Mini-Symposium, we review novel, exciting, and sometimes controversial, findings that substantiate a major role for $\mathrm{Zn}^{2+}$ in the physiological and pathological functioning of the brain.

\section{$\mathrm{Zn}^{2+}$ and synaptic function}

Free or "chelatable" $\mathrm{Zn}^{2+}$ is concentrated within synaptic vesicles at glutamatergic terminals through the activity of the specific transporter ZnT3 (Paoletti et al., 2009). The role of synaptic $\mathrm{Zn}^{2+}$ in regulating plasticity has been addressed either using extracellular metal chelators or in animal models lacking synaptic $\mathrm{Zn}^{2+}$ (ZnT3 KO and the Mocha mutation), but the precise roles this ion plays in synaptic function is still controversial. While some studies suggest that long-term potentiation (LTP) and synaptic excitability in CA3 hippocampal neurons are unaffected by $\mathrm{Zn}^{2+}$ under physiological conditions (Vogt et al., 2000; Lopantsev et al., 2003), others reports have shown the opposite (Li et al., 2001; Huang et al., 2008). In CA3 hippocampal neurons, $\mathrm{Zn}^{2+}$ can directly promote the transactivation of the BDNFrelated TrkB pathway (Huang et al., 2008); however, TrkB signaling can also be activated by extracellular $\mathrm{Zn}^{2+}$ in a metalloproteinase-dependent manner by releasing pro-BDNF and converting it to mature BDNF (Hwang et al., 2005). Paralleling these in vitro $\mathrm{Zn}^{2+}$-mediated neurotrophic effects, chronic dietary treatment with $\mathrm{Zn}^{2+}$ has been found to induce an increase of brain levels of BDNF (Nowak et al., 2004; Corona et al., 2010) (Fig. 3B). It should be noted that in CA3 neurons, BDNF has been shown to activate $\mathrm{Zn}^{2+}$ independent $\mathrm{Ca}^{2+}$ current that is mediated by TRPC3 channels (Li et al., 2010).

$\mathrm{Zn}^{2+}$ also modulates LTP in the amygdala through regulation of feedforward GABAergic inhibition (Kodirov et al., 2006). A direct role for synaptic $\mathrm{Zn}^{2+}$ in learning and memory has been only recently uncovered. ZnT3 KO mice exhibit clear cognitive deficits, but only in animals aged beyond 6 months (Adlard et al., 2010). In other studies, 3- to 4-month-old ZnT3 KO animals show impaired contextual discrimination, spatial working mem- 

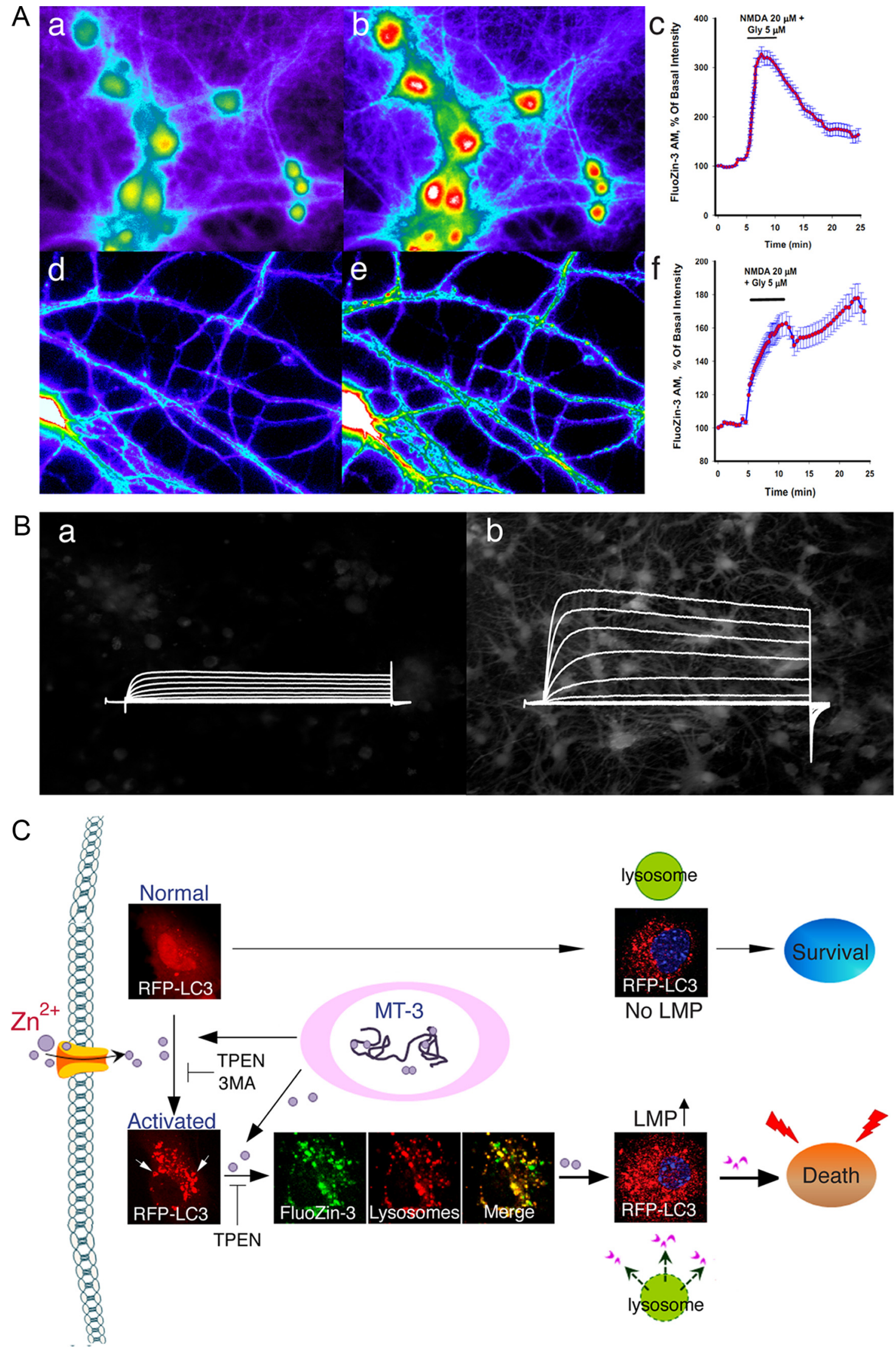

Figure 2. $\quad \mathrm{Zn}^{2+}$-mediated neuronal death and dysfunction. $A$, NMDAR activation induces $\left[\mathrm{Zn}^{2+}\right]_{i}$ mobilization in neuronal soma and dendrites. Neurons loaded with the $\mathrm{Zn}{ }^{2+}-$ selective probe FluoZin3-AM $(\boldsymbol{a}, \boldsymbol{d})$ were exposed to NMDA $(20 \mu \mathrm{m})$ for $5 \mathrm{~min}$. NMDAR activation induces $\left[\mathrm{Zn}^{2+}\right]_{\mathrm{r}}$ rises $(\boldsymbol{b}, \boldsymbol{e})$ that show a different profile when analyzing changes in neuronal somata (Figure legend continues.) 
ory, or learned fear extinction (Martel et al., 2010; Martel et al., 2011; Sindreu et al., 2011).

Among the targets of synaptic $\mathrm{Zn}^{2+}$, NMDA receptors (NMDARs) are rather unique as they display very high sensitivity to extracellular $\mathrm{Zn}^{2+}$ (Paoletti et al., 1997; Traynelis et al., 1998). At low nanomolar concentrations, $\mathrm{Zn}^{2+}$ allosterically inhibits the activity of NMDARs containing the GluN2A subunit, a subunit that is widespread in the adult CNS. The cation acts on a discrete $\mathrm{Zn}^{2+}$-binding site located in the large bilobate $\mathrm{N}$-terminal domain of the GluN2A subunit (Fig. 1A) (Paoletti et al., 2000). The $\mathrm{Zn}^{2+}$-GluN2A interaction likely mediates tonic inhibition of NMDARs by ambient $\mathrm{Zn}^{2+}$ levels. At higher $\mathrm{Zn}^{2+}$ concentrations (micromolar range), such as may occur during phasic synaptic release, $\mathrm{Zn}^{2+}$ binds to the $\mathrm{N}$-terminal domain of the GluN2B subunit, thereby inhibiting GluN2B-containing receptors (Rachline et al., 2005). The in vivo relevance of the highaffinity $\mathrm{Zn}^{2+}$ inhibition of NMDARs has been recently addressed using a knock-in (KI) mouse line in which the GluN2A $\mathrm{Zn}^{2+}$ site has been specifically eliminated. GluN2A-KI mice display a pronounced pain phenotype, showing both hypersensitivity to acute thermal and chemical nociception and enhanced allodynia in models of inflammatory and neuropathic pain (Nozaki et al., 2011). Moreover, in the KI animals, analgesia produced by exogenous $\mathrm{Zn}^{2+}$ administrations is completely suppressed, revealing an essential role of the $\mathrm{Zn}^{2+}$-GluN2A interaction in the painrelieving effects of the cation (Nozaki et al., 2011).

Synaptic $\mathrm{Zn}^{2+}$ also interacts with a selective metabotropic receptor, the $\mathrm{mZnR}$, which has been recently identified as the previously orphan G-protein-linked receptor GPR39 (Fig. 1B) (Besser et al., 2009). $\mathrm{Zn}^{2+}$ released from mossy fibers directly and specifically activates the $\mathrm{mZnR}$ in CA3 hippocampal neurons. The $\mathrm{mZnR}$ response is mediated by a $\mathrm{G}_{\mathrm{q}}$-coupled pathway that triggers IP3 production, followed by $\mathrm{Ca}^{2+}$ release from thapsigargin-sensitive stores. Subsequent activation of MAPK and CAMKII-dependent pathways has also been demonstrated. Employment of mice lacking GPR39 revealed that the ZnRdependent $\mathrm{Ca}^{2+}$ response requires this protein. The $\mathrm{mZnR}$ is likely to modulate neuronal excitability as its activation enhances KCC2 function and $\mathrm{Cl}^{-}$efflux in postsynaptic neurons, thereby inducing a pronounced hyperpolarizing shift in the $\mathrm{GABA}_{\mathrm{A}}$ reversal potential (Chorin et al., 2011). Notably, this effect is absent in GPR39 $\mathrm{KO}$ or ZnT3 KO mice lacking mZnR or synaptic $\mathrm{Zn}^{2+}$, respectively. Thus, synaptic $\mathrm{Zn}^{2+}$-dependent enhancement of KCC2 function, via the $\mathrm{mZnR}$, alters the $\mathrm{Cl}^{-}$gradient and may potentiate $\mathrm{GABA}_{\mathrm{A}}$ receptor-mediated inhibition. Synaptic $\mathrm{Zn}^{2+}$ deficiency, induced by decreased dietary intake, acute chelation, or genetic manipulations, leads to enhanced susceptibility to seizures (Fukahori and Itoh, 1990; Cole et al., 2000; Blasco-Ibáñez et al., 2004). Based on these results and the documented role of

\section{$\leftarrow$}

(Figure legend continued.) (c) compared to dendrites ( $\boldsymbol{f}$ ). Time course graphs show changes in fluorescence levels in neuronal somata and dendrites before and after the NMDA challenge, respectively. Note how the dendritic $\left[\mathrm{Zn}^{2+}\right]_{\mathrm{i}}$ rises are long lasting, while in the soma, $\left[\mathrm{Zn}^{2+}\right]_{\mathrm{i}}$ levels rapidly recover to baseline. $B, A \mathrm{Zn}^{2+}-\mathrm{K}^{+}$continuum in neuronal apoptosis. Oxidant exposure in neurons $(\boldsymbol{a})$ results in the liberation of $\mathrm{Zn}^{2+}$ from intracellular metal binding proteins $(\boldsymbol{b})$. This $\mathrm{Zn}^{2+}$ activates a signaling cascade that ultimately produces a robust enhancement of voltage-activated delayed rectifier $\mathrm{K}^{+}$currents $(\boldsymbol{b})$. This, in turn, leads to the loss of intracellular $\mathrm{K}^{+}$, creating a permissive environment for the completion of apoptotic programs. $C, Z^{2+}$ influx or intracellular $\mathrm{Zn}^{2+}$ release from metallothionein 3 (MT-3) activates autophagy and causes accumulation of $\mathrm{Zn}^{2+}$ in autophagosomes and autolysosomes. Under physiological conditions, activated autophagy serves beneficial functions by removing abnormal proteins and organelles. However, when in excess, it leads to LMP and neuronal death.
KCC2 in epilepsy, we suggest that the mZnR may provide a crucial link between activity-dependent release of synaptic $\mathrm{Zn}^{2+}$ and modulation of neuronal inhibition.

\section{$\mathrm{Zn}^{2+}$-dependent injury: a death by multiple cuts}

$\mathrm{Zn}^{2+}$ promotes neuronal death by affecting multiple systems. $\mathrm{Zn}^{2+}$ can induce profound mitochondrial dysfunction by being sequestered in that organelle (for review, see Sensi et al., 2009). $\mathrm{Zn}^{2+}$ can trigger mitochondrial depolarization and the generation of reactive oxygen species (ROS) (Sensi et al., 1999, 2000; Dineley et al., 2005). These events, once investigated only in the neuronal somata, are now also identified in dendrites where they show a specific temporal pattern that differs from that found in the soma. This phenomenon may serve as primum movens for neuronal deafferentation and subsequent death (Medvedeva et al., 2009; Frazzini et al., 2011) (Fig. 2A).

Furthermore, $\mathrm{Zn}^{2+}$ induces a multiconductance cation channel activity in the inner mitochondrial membrane that is consistent with the activation of the mitochondrial permeability transition pore (mPTP; Jiang et al., 2001; Sensi et al., 2003; Gazaryan et al., 2007), thereby leading to release of pro-apoptotic mitochondrial proteins such as cytochrome $\mathrm{C}(\mathrm{Cyt}-\mathrm{C})$ and apoptosis-inducing factor (AIF) (Jiang et al., 2001). $\mathrm{Zn}^{2+}$ can also profoundly affect mitochondrial trafficking and morphology (Malaiyandi et al., 2005).

$\mathrm{Zn}^{2+}$ deregulation favors neuronal death by increasing cytosolic oxidative stress through PKC (protein kinase $\mathrm{C}$ )-dependent activation of NADPH oxidase (Kim et al., 1999; Noh et al., 1999) as well as by activating the neuronal isoform of nitric oxide synthase (Kim et al., 1999; Kim and Koh, 2002). Moreover, $\mathrm{Zn}^{2+}$ triggers a lethal depletion of neuronal ATP by inhibiting the GAPDH (glyceraldehyde-3-phosphate dehydrogenase) enzyme, a process mediated by the reduction of cytosolic $\mathrm{NAD}^{+}$(Sheline et al., 2000) and reverted by pyruvate (Sheline et al., 2000). Evidence also indicates that $\mathrm{Zn}^{2+}$-mediated $\mathrm{NAD}^{+}$depletion requires the activation of the sirtuin pathway as SIRT proteins are $\mathrm{NAD}^{+}$-catabolic protein deacetylases and sirtuin inhibitors are neuroprotective against both acute and chronic $\mathrm{Zn}^{2+}$-dependent toxicity, while, on the contrary, sirtuin activators promote $\mathrm{NAD}^{+}$depletion and neuronal death (Cai et al., 2006).

$\mathrm{Zn}^{2+}$ also triggers autophagic neuronal death (Hwang et al., 2008). Lysosomes are the organelles in which autophagic degradation occurs. Lysosomal hydrolases released into the cytosol promote cell death by breaking down cellular components as well as by activating death inducers such as BID through a process termed lysosomal membrane permeabilization (LMP). Recently, evidence has indicated that LMP is a key contributing mechanism in oxidative- and $\mathrm{Zn}^{2+}$-induced hippocampal neuronal death (Hwang et al., 2008). Following exposure to $\mathrm{H}_{2} \mathrm{O}_{2}$ or toxic levels of $\mathrm{Zn}^{2+}, \mathrm{Zn}^{2+}$ rapidly accumulates in lysosomes and $\mathrm{Zn}^{2+}$ laden lysosomes undergo membrane disintegration releasing the toxic enzyme cathepsin. Exposure to the cell-permeable $\mathrm{Zn}^{2+}$ chelator tetrakis(2-pyridylmethyl)ethylenediamine (TPEN) not only completely blocks lysosomal $\mathrm{Zn}^{2+}$ rises but also inhibits LMP. Thus, $\mathrm{Zn}^{2+}$ deregulation may function as a linker between oxidative stress and LMP; however, what favors $\mathrm{Zn}^{2+}$ accumulation in lysosomes under oxidative conditions is still completely unknown. $\mathrm{Zn}^{2+}$ may enter lysosomes through $\mathrm{Zn}^{2+}$ transporters, $\mathrm{Zn}^{2+}$-permeable channels, or exchangers. Alternatively, $\mathrm{Zn}^{2+}$ may be released inside lysosomes from proteins, but the precise inter-organelle dynamics of $\mathrm{Zn}^{2+}$ inside cells warrant further investigations. 
A

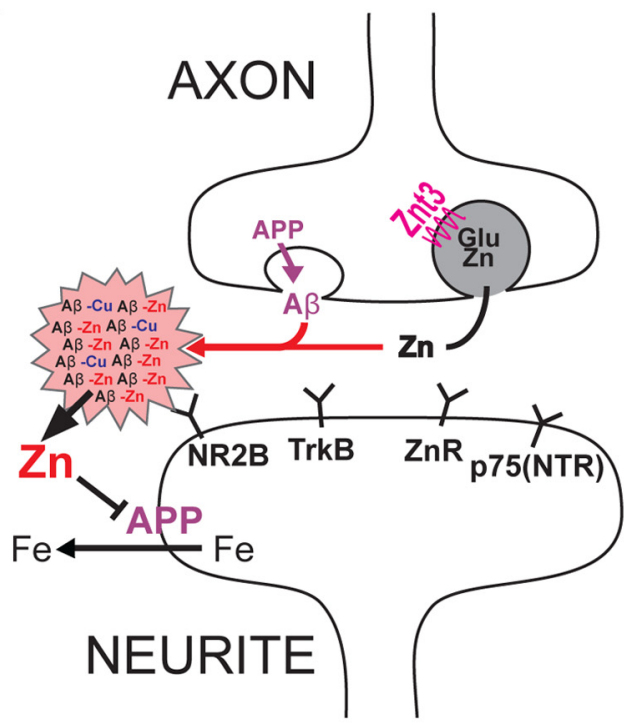

B
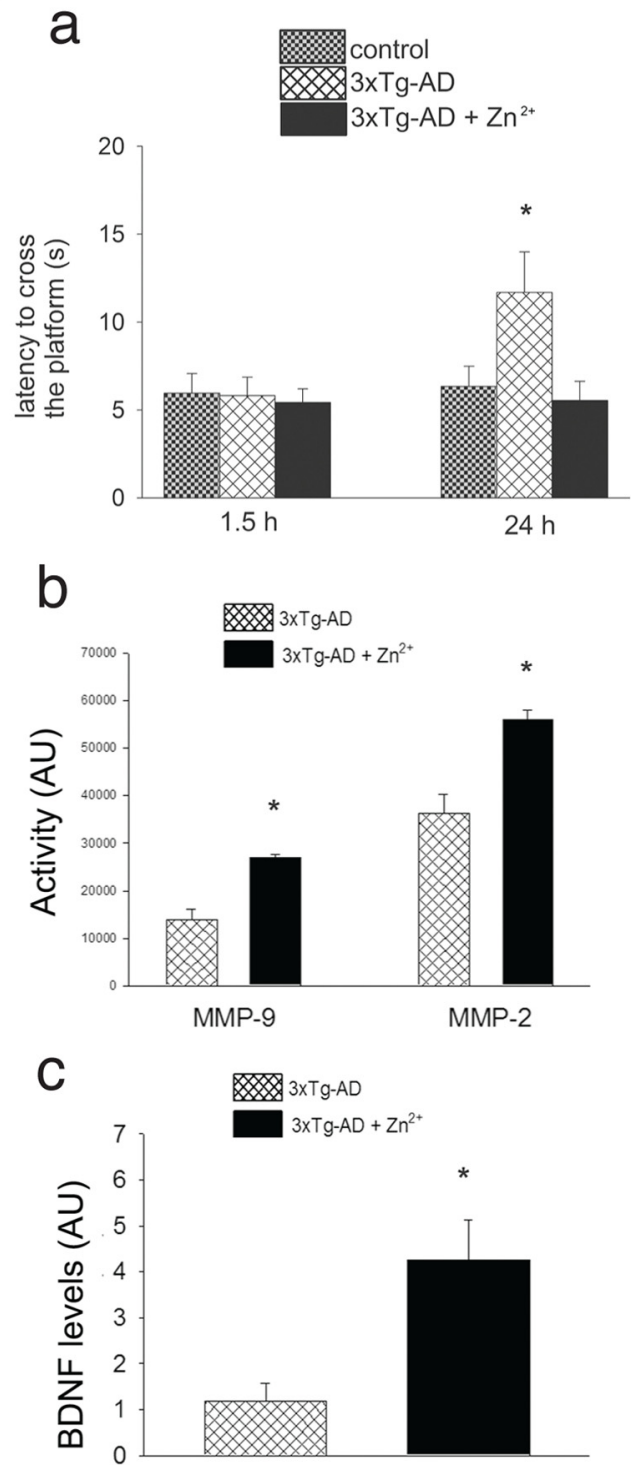

Figure 3. $\mathrm{Zn}^{2+}$ in Alzheimer's disease. $A, \mathrm{Zn}^{2+}$ released during neurotransmission is trapped by amyloid, depriving targets essential for LTP. In addition, the $\mathrm{Zn}^{2+}$ transfers inappropriately
Interestingly, $\mathrm{Zn}^{2+}$ deprivation can also be a trigger for neuronal death and a converging set of evidence indicates that, most likely, neurons possess a finely tuned " $\mathrm{Zn}^{2+}$ set-point." In this respect, even though chelation of deregulated $\left[\mathrm{Zn}^{2+}\right]_{\mathrm{i}}$ is neuroprotective, excessive depletion of $\left[\mathrm{Zn}^{2+}\right]_{i}$ by high-affinity cellpermeable $\mathrm{Zn}^{2+}$ chelators can be lethal (Lee et al., 2008). $\mathrm{Zn}^{2+}$ depletion can enhance endonuclease activity (Vincent and Maiese, 1999; Vincent et al., 1999) as well as counteract neuronal apoptosis by inhibiting Bax and Bak activation (Ganju and Eastman, 2003). In addition $\mathrm{Zn}^{2+}$ chelation by TPEN promotes neuronal apoptosis by inducing caspase- 11 and caspase- 3 activation (Lee et al., 2008). TPEN-induced $\mathrm{Zn}^{2+}$ depletion also favors a "dying-back" pattern of axon and dendrite degeneration due to $\mathrm{Zn}^{2+}$-mediated ATP depletion and autophagy (Yang et al., 2007).

The possibility of neuronal injury triggered by $\mathrm{Zn}^{2+}$ depletion should be considered in light of the fact that $\mathrm{Zn}^{2+}$-chelating strategies have been proposed as therapeutic measures in the aftermath of an ischemic insult as well as for the treatment of $\mathrm{AD}$ (Corona et al., 2011). The idea of a $\mathrm{Zn}^{2+}$ set-point is further substantiated within the context of $\mathrm{AD}$ as recent findings indicate that, in an $\mathrm{AD}$ mouse model, dietary supplementation of the cation starting as early as 1-month-old animals largely prevents the development of age-dependent mitochondrial dysfunction and hippocampal-dependent cognitive deficits and induces a potent increase in BDNF levels (Fig. 3B) (Corona et al., 2010).

\section{$\mathrm{Zn}^{2+}$ dyshomeostasis and ischemic neuronal injury}

A series of recent studies has promoted a reevaluation of the "calcium-centric" hypothesis that has dominated the field of ischemic neuronal death in the past three decades (Choi, 1988). Real-time "single-cell" ionic imaging techniques have in fact shown that $\mathrm{Ca}^{2+}$ works in synergy with $\mathrm{Zn}^{2+}$ to promote ischemic death. $\mathrm{Ca}^{2+}$ imaging in acute hippocampal slices undergoing oxygen and glucose deprivation (OGD; an in vitro model of brain ischemia) using a low-affinity $\mathrm{Ca}^{2+}$-sensitive probe has shown that the OGD-driven increase in the probe fluorescence is substantially stunted (by 70\%) by TPEN, indicating that, at least in some models, ischemia promotes a parallel, and possibly interdependent, surge of $\left[\mathrm{Ca}^{2+}\right]_{\mathrm{i}}$ and $\left[\mathrm{Zn}^{2+}\right]_{\mathrm{i}}$ (Stork and $\mathrm{Li}, 2006$ ).

Indeed, analyzing the ionic changes of CA1 pyramidal neurons exposed to OGD, a more recent study has dissected the interplay between the two cations. The study showed that, within few minutes after OGD induction, neurons undergo $\mathrm{Ca}^{2+}$ deregulation and irreversible alteration of plasma membrane permeability (Medvedeva et al., 2009). Surprisingly, both processes are

$\longleftarrow$

to APP and inhibits its ferroxidase activity and ability to facilitate iron release from neurons, leading to pro-oxidant intraneuronal iron accumulation as a downstream consequence of extracellular $\mathrm{Zn}^{2+}$ accumulation. $\boldsymbol{B}, \mathrm{Zn}^{2+}$ supplementation is beneficial in an animal model of $A D$. 3xTg-AD mice chronically fed (11-13 months) with water containing $30 \mathrm{ppm}$ of $\mathrm{ZnSO}_{4}$ are protected from the appearance at 12-14 months of age of hippocampus-dependent memory deficits (as assessed with the Morris water maze test). Mice were tested when the platform was removed $1.5 \mathrm{~h}$ ( $\boldsymbol{a}$, left panel; to investigate short-term memory) and $24 \mathrm{~h}$ ( $\boldsymbol{a}$, right panel; to investigate long-term memory) after the last training trial. $\mathrm{Zn}^{2+}$-fed $3 x \mathrm{Tg}-\mathrm{AD}$ mice exhibited a marked recovery in their long-term memory as indicated by the decreased time (latency) they used to reach the point where the platform used to be. $\boldsymbol{b}, \mathrm{Zn}^{2+}$ supplementation promotes metalloproteinase (MMPs) activation in 3xTg-AD mice as shown by gelatin zymography indicating a significant increase of MMP-2 and MMP-9 induction in 3xTg-AD mice brains. $c$, BDNF immunoblotting reveals that $\mathrm{Zn}^{2+}$-fed $3 x \mathrm{Tg}-\mathrm{AD}$ mice showed a fourfold increase in BDNF levels compared to untreated mice (modified from Corona et al., 2010). Error bars indicate mean values \pm SEM. ${ }^{*}$ indicates $p<0.05$ in $\boldsymbol{a}$ and $\boldsymbol{c}$ and $p<0.01$ in $\boldsymbol{b}$. 
preceded by elevations in $\left[\mathrm{Zn}^{2+}\right]_{\mathrm{i}}$ and associated with mitochondrial $\mathrm{Zn}^{2+}$ uptake as well as with depolarization and $\left[\mathrm{Zn}^{2+}\right]_{\mathrm{i}}$ chelation with TPEN results in delaying the phenomena (Medvedeva et al., 2009). A novel link explaining the synergistic deregulation of the two cations is offered by the downstream effects produced by glutamate and $\mathrm{Ca}^{2+}$ influx on the acidification of the neuronal cytosol. Acidosis is a potent trigger for $\mathrm{Zn}^{2+}$ mobilization from MTs and a recent study indicates that glutamate/ $\mathrm{Ca}^{2+}$ influx leads to acidification of the neuronal cytosol, and that this is key to promote neuronal $\left[\mathrm{Zn}^{2+}\right]_{\mathrm{i}}$ rises (Kiedrowski, 2011). Synaptically released $\mathrm{Zn}^{2+}$ can promote ischemic neuronal death (especially in TGI) by entering postsynaptic neurons through routes that are used by $\mathrm{Ca}^{2+}$, such as NMDARs and voltage-sensitive $\mathrm{Ca}^{2+}$ channels (VSCC), however most $\mathrm{Zn}^{2+}$ preferentially fluxes through $\mathrm{Ca}^{2+}$-and $\mathrm{Zn}^{2+}$-permeable GluA2lacking AMPA receptors (Ca/ARs; for review, see Sensi et al., 2009). Ca/ARs are highly expressed and dynamically upregulated after TGI (Pellegrini-Giampietro et al., 1997) on postsynaptic membranes in the dendritic tree of TGI-vulnerable neurons and their pharmacological inhibition prevents $\mathrm{Zn}^{2+}$ influx and is highly neuroprotective in brain slices undergoing OGD or in animals exposed to TGI (Yin et al., 2002; Noh et al., 2005).

TGI-related apoptosis is also modulated by $\mathrm{Zn}^{2+}$ as the cation induces $\mathrm{mPTP}$ opening in isolated postischemic mitochondria extracted immediately after TGI and these intramitochondrial $\mathrm{Zn}^{2+}$ increases are linked to increased proteolytic cleavage of BCL-xL and the accumulation of the pro-apoptotic byproduct, deltaN-BCL-xL (Bonanni et al., 2006). Furthermore, the extracellular $\mathrm{Zn}^{2+}$ chelator, clioquinol (CQ), is neuroprotective and decreases the expression levels of caspase- 3 and -9 and AIF in the hippocampus of CQ-treated gerbils undergoing ischemia (Wang et al., 2010).

Neurons can be also killed by intraneuronal mobilization of the metal. Studies using ZnT3KO mice have, in fact, shown that glutamate-driven $\left[\mathrm{Zn}^{2+}\right]_{\mathrm{i}}$ accumulation can result from $\mathrm{Zn}^{2+}$ released from sources such as MTs, mitochondria, and lysosomes (for review, see Sensi et al., 2009).

MTs are key players in excitotoxic and ischemic injury as they release $\mathrm{Zn}^{2+}$ upon oxidative stress, a phenomenon occurring in neurons and glia (Aizenman et al., 2000; Malaiyandi et al., 2001, 2004) that can lead to both caspase-dependent and caspaseindependent forms of cell death (Aizenman et al., 2000; McLaughlin et al., 2001; Du et al., 2002). In the case of caspasedependent cell death, the liberated $\mathrm{Zn}^{2+}$ triggers a signaling cascade that creates a permissive environment for the effective activation of proteases and nucleases. $\mathrm{K}^{+}$is a key modulator of this process as cells undergoing caspase-mediated death develop an early, robust drop of intracellular $\mathrm{K}^{+}$levels (Yu et al., 1997; Hughes and Cidlowski, 1999) reaching, in some cases, a final concentration of $50 \mathrm{~mm}$ (Hughes et al., 1997). This loss of $\left[\mathrm{K}^{+}\right]_{\mathrm{i}}$ favors the activation of caspases, including caspase 3 , while the process and the subsequent neuronal death is inhibited when $\left[\mathrm{K}^{+}\right]_{\mathrm{i}}$ is maintained at physiological levels (Bortner et al., 1997; Hughes et al., 1997; Yu et al., 1997). In cortical and midbrain neurons, $\mathrm{K}^{+}$efflux is facilitated by a dramatic enhancement of delayed rectifier, voltage-activated $\mathrm{K}^{+}$currents mediated by Kv2.1-encoded channels (Fig. 2 B) (McLaughlin et al., 2001; Pal et al., 2003; Redman et al., 2006). This $\mathrm{K}^{+}$current surge results from the following series of events: (1) $\mathrm{Zn}^{2+}$-dependent activation of Src kinase in parallel to $\mathrm{Zn}^{2+}$-induced inhibition of protein tyrosine phosphatase $\varepsilon(\mathrm{PTP} \varepsilon)$, ensuring phosphorylation of Kv2.1 N-terminal tyrosine residue Y124 (Redman et al., 2009); (2) $\mathrm{Zn}^{2+}$-triggered activation of p38 MAPK via the MAP3K ap- optosis signaling kinase-1 (ASK-1; McLaughlin et al., 2001; Aras and Aizenman, 2005), resulting in the phosphorylation of Kv2.1 C-terminal serine residue S800 (Redman et al., 2007, 2009), and (3) exocytotic, SNARE-dependent membrane insertion of the Y124/S800 dual-phosphorylated Kv2.1 channel, leading to enhanced $\mathrm{K}^{+}$current densities (Pal et al., 2003, 2006). Preventing the rise of intracellular $\mathrm{Zn}^{2+}$ (McLaughlin et al., 2001), blocking any of the signaling steps along the pathway (McLaughlin et al., 2001; Pal et al., 2004, 2006; Aras and Aizenman, 2011), or interfering with the functional expression or membrane insertion of Kv2.1 (Pal et al., 2003, 2006) is sufficient to prevent neuronal death following oxidative, nitrosative, or chemical injury. Indeed, targeting the $\mathrm{K}^{+}$current surge-signaling pathway might provide novel therapeutic strategies in neuroprotection (Aras and Aizenman, 2011).

$\mathrm{Zn}^{2+}$ can also affect $\mathrm{Cl}^{-}$homeostasis as a recent study reported that $\left[\mathrm{Zn}^{2+}\right]_{\mathrm{i}}$ rises inhibit the activity of the $\mathrm{K}^{+} / \mathrm{Cl}^{-}$ cotransporter-2 (KCC2), the major $\mathrm{Cl}^{-}$outward transporter in neurons and thereby a key determinant of GABAergic neurotransmission (Hershfinkel et al., 2009). OGD-triggered $\left[\mathrm{Zn}^{2+}\right]_{\mathrm{i}}$ rises are followed by a profound KCC2 inhibition and a depolarizing shift in the $\mathrm{GABA}_{\mathrm{A}}$ reversal potential, a process reversed by intraneuronal $\mathrm{Zn}^{2+}$ chelation. This process again indicates that $\left[\mathrm{Zn}^{2+}\right]_{\mathrm{i}}$ dyshomeostasis is an early and critical component of ischemic injury.

Adding a new angle to $\mathrm{Zn}^{2+}$-dependent ischemic neuronal loss, evidence indicates that the cation also promotes injury by inhibiting the ubiquitin-proteasome system (Chen et al., 2009). Recent evidence in brain slices undergoing OGD also indicates that $\mathrm{Zn}^{2+}$ favors ischemic spreading depression, a wave of neuronal and glial depolarization that is thought to be a contributing factor in the enlargement of the infarct area (Carter et al., 2011).

Parenchymal acidosis is also a key modulator of $\mathrm{Zn}^{2+}$ dyshomeostasis upon cerebral ischemia. Ischemic acidosis can increase $\mathrm{Zn}^{2+}$ influx through VSCC and Ca/ARs and promote $\mathrm{Zn}^{2+}$ release from MTs, thereby favoring an overall neurotoxic increase in $\left[\mathrm{Zn}^{2+}\right]_{\mathrm{i}}$ levels (Jiang et al., 2000; Sensi et al., 2003; Frazzini et al., 2007). As protons also block NMDARs, ischemic acidosis can therefore serve as a switch to decrease NMDAR-mediated neuronal death while potentiating injury triggered by the activation of VSCC and AMPARs. Data from cultured neurons indicate that, in fact, AMPAR activation promotes ROS-mediated $\left[\mathrm{Zn}^{2+}\right]_{\mathrm{i}}$ rises that are enhanced by mild acidosis (Frazzini et al., 2007). Interestingly, $\mathrm{Zn}^{2+}$ can itself disrupt the neuronal acid-base equilibrium by blocking the $\mathrm{Na}^{+} / \mathrm{H}^{+}$exchanger, thereby creating a feedforward loop as the cation promotes intracellular acidification and also delays recovery from intracellular acidification (Dineley et al., 2002).

\section{$\mathrm{Zn}^{2+}$ in Alzheimer's disease}

$\mathrm{A} \beta$ accumulation in the neocortex in $\mathrm{AD}$ is pathognomonic of $\mathrm{AD}$, yet the mere production of this ubiquitously expressed 39-43 residue peptide does not offer explanations for why amyloid only forms in the neocortex, why mice and rats do not develop amyloid pathology with age, or why women and APP transgenic mice have accelerated amyloid formation. The exceptional colocalization of $\mathrm{A} \beta$ and $\mathrm{Zn}^{2+}$ in the glutamatergic synapses of the neocortex offers plausible explanations (Fig. $3 A$ ). $\mathrm{Zn}^{2+}$ induces the rapid, but reversible, aggregation of $\mathrm{A} \beta$ into amyloid precipitates (Bush et al., 1994; Cherny et al., 1999), the pathological hallmark of $\mathrm{AD}$. The rat/mouse $\mathrm{A} \beta$ possesses three amino acid substitutions that attenuate the interaction of $\mathrm{Zn}^{2+}$ and prevent $\mathrm{Zn}^{2+}$-induced precipitation (Bush et al., 1994). As 
described earlier, $\mathrm{Zn}^{2+}$ is released in a dissociable form by glutamatergic fibers in the cortex and hippocampus, and ZnT3 loads $\mathrm{Zn}^{2+}$ into these synaptic vesicles. The distribution of ZnT3 expression closely approximates with the anatomical sites of $\mathrm{A} \beta$ deposition. ZnT3 is not appreciably expressed outside of the brain, and therefore the synaptic release of $\mathrm{Zn}^{2+}$ in the neocortex is a cogent explanation for why $\mathrm{A} \beta$, which is released in the same vicinity, is liable to precipitate only in the brain. While several reports have found $\mathrm{Zn}^{2+}$ to be enriched in extracellular amyloid deposits (Lovell et al., 1998; Lee et al., 1999; Miller et al., 2006; Adlard et al., 2008), this represents only a small fraction of the total cortical volume, and the tissue total $\mathrm{Zn}^{2+}$ concentrations only rise during advanced pathology (Religa et al., 2006).

Genetic ablation of ZnT3 abolishes interstitial (Lee et al., 2002) and vessel-wall (Friedlich et al., 2004) amyloid pathology in transgenic mice overexpressing human $\mathrm{A} \beta$. The increase in the levels of soluble $\mathrm{A} \beta$ in the brains of the APP transgenic $\times \mathrm{ZnT} 3$ $\mathrm{KO}$ mice (Lee et al., 2002) confirmed that $\mathrm{Zn}^{2+}$ holds the amyloid mass in a dissociable equilibrium (Huang et al., 1997). Ablation of ZnT3 also abolished the difference in genders for this mouse model in amyloid burden. Female mice have greater levels of dissociable $\mathrm{Zn}^{2+}$ in this system (Lee et al., 2002), and ovariectomy raises hippocampal synaptic vesicle $\mathrm{Zn}^{2+}$ levels further, whereas estrogen replacement opposed this rise (Lee et al., 2004).

As mentioned above, $\mathrm{Zn}^{2+}$ may be a key modulator of synaptic activity and substrate for LTP. This may explain why ZnT3 KO mice develop a cognitive and memory loss by the age of 6 months, becoming a phenocopy for the cognitive loss seen in the $\mathrm{AD}$ model transgenic $\mathrm{A} \beta$ overexpressors (Adlard et al., 2010). Therefore, by trapping extracellular $\mathrm{Zn}^{2+}$, amyloid pathology may deprive these targets of physiological $\mathrm{Zn}^{2+}$ and so contribute to downstream cognitive loss through a variety of mechanisms. At the same time, $\mathrm{Zn}^{2+}$ flux through the NMDAR promotes the attachment of $A \beta$ oligomers to the NR2B subunit, which may also impair LTP, but can be reversed by treatment with the $\mathrm{Zn}^{2+}$ ionophore, CQ (Deshpande et al., 2009). This ionophoric mechanism that liberates $\mathrm{Zn}^{2+}$ from $\mathrm{A} \beta$ oligomers, returning $\mathrm{Zn}^{2+}$ to the relatively deficient neighboring cells, may explain the rapid benefits of PBT2 (an analog of CQ) on cognition and neurite outgrowth in $\mathrm{AD}$ animal and cell culture models (Adlard et al., 2008,2011 ), as well as the rapid efficacy of the drug candidate in a phase 2 clinical trial of AD patients (Lannfelt et al., 2008; Faux et al., 2010).

The trapping of $\mathrm{Zn}^{2+}$ by extracellular amyloid also impacts upon neuronal iron homeostasis. The amyloid protein precursor (APP) is a ferroxidase that catalytically loads $\mathrm{Fe}^{3+}$ into transferrin, and is required for optimal iron export from neurons (Duce et al., 2010). Brain neuronal iron levels are increased in APP knock-out mice, as well as in $\mathrm{AD}$, which provokes oxidative damage (Smith and Goldin, 1997; Duce et al., 2010). APP ferroxidase activity is $75 \%$ decreased in $\mathrm{AD}$ cortical tissue, caused by dissociation of $\mathrm{Zn}^{2+}$ from amyloid, and not caused by a decrease in APP levels (Duce et al., 2010). Abnormal iron homeostasis can also have broad sequelae on heme synthesis, and is another of the downstream ramifications of $\mathrm{Zn}^{2+}$ trapping by amyloid.

One major question to be answered is why extracellular $\mathrm{Zn}^{2+}$ begins to react with soluble $A \beta$ with advanced aging. Extracellular $\mathrm{A} \beta$ concentrations are elevated in uncommon familial $\mathrm{AD}$ mutations, but there is no evidence of an elevation with age in sporadic cases. The prediction is that extracellular $\mathrm{Zn}^{2+}$ levels may rise with age. $\mathrm{Zn}^{2+}$ coreleased with glutamate in the synapse must be, like glutamate, taken back into the cells by a very rapid transport with a pattern of $\mathrm{Zn}^{2+}$ levels in the synaptic cleft that is likely to not be steady, but rather rapidly sinusoidal. There is no evidence for increased synaptic $\mathrm{Zn}^{2+}$ in $\mathrm{AD}$, but it is possible that $\mathrm{Zn}^{2+}$ reuptake, which is energy dependent, may be fatigued with aging. Recent data have implicated the presenilins (PSs), whose mutations cause familial $\mathrm{AD}$, in $\mathrm{Zn}^{2+}$ uptake (Greenough et al., 2011). Together, these data indicate that PS may be able to influence $A \beta$ aggregation by metal ion clearance in the extra-neuronal vicinity, which is currently being studied further.

\section{Conclusions}

Critical new findings have begun to uncover the many physiological roles for synaptically released $\mathrm{Zn}^{2+}$, as well as for intracellularly mobilized $\mathrm{Zn}^{2+}$, acting as an important player in the modulation of neuronal excitability and survival. New territories, however, need to be explored. For instance, the physiopathological activity of $\mathrm{Zn}^{2+}$ in glial cells and how this is factored within the context of neuron-glia interaction requires further investigation. A more detailed road map of the regulatory processes that affect $\mathrm{Zn}^{2+}$ homeostasis and $\mathrm{Zn}^{2+}$-dependent signaling is also needed. All these steps are crucial to find better pharmacological tools able to modulate cellular $\mathrm{Zn}^{2+}$. These drugs are urgently needed as they are likely to have an important impact in the management of major neurological conditions like AD, epilepsy, and stroke.

\section{References}

Adlard PA, Cherny RA, Finkelstein DI, Gautier E, Robb E, Cortes M, Volitakis I, Liu X, Smith JP, Perez K, Laughton K, Li QX, Charman SA, Nicolazzo JA, Wilkins S, Deleva K, Lynch T, Kok G, Ritchie CW, Tanzi RE, et al. (2008) Rapid restoration of cognition in Alzheimer's transgenic mice with 8-hydroxy quinoline analogs is associated with decreased interstitial Abeta. Neuron 59:43-55.

Adlard PA, Parncutt JM, Finkelstein DI, Bush AI (2010) Cognitive loss in zinc transporter-3 knock-out mice: a phenocopy for the synaptic and memory deficits of Alzheimer's disease? J Neurosci 30:1631-1636.

Adlard PA, Bica L, White AR, Nurjono M, Filiz G, Crouch PJ, Donnelly PS, Cappai R, Finkelstein DI, Bush AI (2011) Metal ionophore treatment restores dendritic spine density and synaptic protein levels in a mouse model of Alzheimer's disease. PLoS ONE 6:e17669.

Aizenman E, Stout AK, Hartnett KA, Dineley KE, McLaughlin B, Reynolds If (2000) Induction of neuronal apoptosis by thiol oxidation: putative role of intracellular zinc release. J Neurochem 75:1878-1888.

Aras MA, Aizenman E (2005) Obligatory role of ASK1 in the apoptotic surge of K+ currents. Neurosci Lett 387:136-140.

Aras MA, Aizenman E (2011) Redox regulation of intracellular zinc: molecular signaling in the life and death of neurons. Antioxid Redox Signal 15:2249-2263.

Besser L, Chorin E, Sekler I, Silverman WF, Atkin S, Russell JT, Hershfinkel M (2009) Synaptically released zinc triggers metabotropic signaling via a zinc-sensing receptor in the hippocampus. J Neurosci 29:2890-2901.

Blasco-Ibáñez JM, Poza-Aznar J, Crespo C, Marqués-Marí AI, Gracia-Llanes FJ, Martínez-Guijarro FJ (2004) Chelation of synaptic zinc induces overexcitation in the hilar mossy cells of the rat hippocampus. Neurosci Lett 355:101-104.

Bonanni L, Chachar M, Jover-Mengual T, Li H, Jones A, Yokota H, Ofengeim D, Flannery RJ, Miyawaki T, Cho CH, Polster BM, Pypaert M, Hardwick JM, Sensi SL, Zukin RS, Jonas EA (2006) Zinc-dependent multiconductance channel activity in mitochondria isolated from ischemic brain. J Neurosci 26:6851-6862.

Bortner CD, Hughes FM Jr, Cidlowski JA (1997) A primary role for K+ and $\mathrm{Na}+$ efflux in the activation of apoptosis. J Biol Chem 272:32436-32442.

Bush AI, Pettingell WH, Multhaup G, d Paradis M, Vonsattel JP, Gusella JF, Beyreuther K, Masters CL, Tanzi RE (1994) Rapid induction of Alzheimer A beta amyloid formation by zinc. Science 265:1464-1467.

Cai AL, Zipfel GJ, Sheline CT (2006) Zinc neurotoxicity is dependent on intracellular NAD levels and the sirtuin pathway. Eur J Neurosci 24:2169-2176.

Caporale T, Ciavardelli D, Di Ilio C, Lanuti P, Drago D, Sensi SL (2009) 
Ratiometric-pericam-mt, a novel tool to evaluate intramitochondrial zinc. Exp Neurol 218:228-234.

Carter RE, Aiba I, Dietz RM, Sheline CT, Shuttleworth CW (2011) Spreading depression and related events are significant sources of neuronal $\mathrm{Zn} 2+$ release and accumulation. J Cereb Blood Flow Metab 31:10731084.

Chen M, Chen Q, Cheng XW, Lu TJ, Liu HX, Jia JM, Zhang C, Xu L, Xiong ZQ (2009) Zn2+ mediates ischemia-induced impairment of the ubiquitin-proteasome system in the rat hippocampus. J Neurochem 111:1094-1103.

Cherny RA, Legg JT, McLean CA, Fairlie DP, Huang X, Atwood CS, Beyreuther K, Tanzi RE, Masters CL, Bush AI (1999) Aqueous dissolution of Alzheimer's disease Aß amyloid deposits by biometal depletion. J Biol Chem 274:23223-23228.

Choi DW (1988) Calcium-mediated neurotoxicity: relationship to specific channel types and role of ischemic damage. Trends Neurosci 11:465-469.

Choi DW, Yokoyama M, Koh J (1988) Zinc neurotoxicity in cortical cell culture. Neuroscience 24:67-79.

Chorin E, Vinograd O, Fleidervish I, Gilad D, Herrmann S, Sekler I, Aizenman E, Hershfinkel M (2011) Upregulation of KCC2 activity by zincmediated neurotransmission via the mZnR/GPR39 receptor. J Neurosci 31:12916-12926.

Cole TB, Robbins CA, Wenzel HJ, Schwartzkroin PA, Palmiter RD (2000) Seizures and neuronal damage in mice lacking vesicular zinc. Epilepsy Res 39:153-169.

Corona C, Masciopinto F, Silvestri E, Viscovo AD, Lattanzio R, Sorda RL, Ciavardelli D, Goglia F, Piantelli M, Canzoniero LM, Sensi SL (2010) Dietary zinc supplementation of 3xTg-AD mice increases BDNF levels and prevents cognitive deficits as well as mitochondrial dysfunction. Cell Death Dis 1:e91.

Corona C, Pensalfini A, Frazzini V, Sensi SL (2011) New therapeutic targets in Alzheimer's disease: brain deregulation of calcium and zinc. Cell Death Dis 2:e176.

Deshpande A, Kawai H, Metherate R, Glabe CG, Busciglio J (2009) A role for synaptic zinc in activity-dependent $\mathrm{A} \beta$ oligomer formation and accumulation at excitatory synapses. J Neurosci 29:4004-4015.

Dineley KE, Brocard JB, Reynolds IJ (2002) Elevated intracellular zinc and altered proton homeostasis in forebrain neurons. Neuroscience 114:439-449.

Dineley KE, Richards LL, Votyakova TV, Reynolds IJ (2005) Zinc causes loss of membrane potential and elevates reactive oxygen species in rat brain mitochondria. Mitochondrion 5:55-65.

Dittmer PJ, Miranda JG, Gorski JA, Palmer AE (2009) Genetically encoded sensors to elucidate spatial distribution of cellular zinc. J Biol Chem 284:16289-16297.

Du S, McLaughlin B, Pal S, Aizenman E (2002) In vitro neurotoxicity of methylisothiazolinone, a commonly used industrial and household biocide, proceeds via a zinc and extracellular signal-regulated kinase mitogen-activated protein kinase-dependent pathway. J Neurosci 22:7408-7416.

Duce JA, Tsatsanis A, Cater MA, James SA, Robb E, Wikhe K, Leong SL, Perez K, Johanssen T, Greenough MA, Cho HH, Galatis D, Moir RD, Masters CL, McLean C, Tanzi RE, Cappai R, Barnham KJ, Ciccotosto GD, Rogers JT, et al. (2010) Iron-export ferroxidase activity of beta-amyloid precursor protein is inhibited by zinc in Alzheimer's disease. Cell 142:857-867.

Faux NG, Ritchie CW, Gunn A, Rembach A, Tsatsanis A, Bedo J, Harrison J, Lannfelt L, Blennow K, Zetterberg H, Ingelsson M, Masters CL, Tanzi RE, Cummings JL, Herd CM, Bush AI (2010) PBT2 rapidly improves cognition in Alzheimer's disease: additional phase II analyses. J Alzheimers Dis 20:509-516.

Frazzini V, Sensi SL (2011) Dendritic Zn2 + rises modulate mitochondrial function and glutamatergic transmission in hippocampal neurons. Soc Neurosci Abstr 37:450.01.

Frazzini V, Rapposelli IG, Corona C, Rockabrand E, Canzoniero LM, Sensi SL (2007) Mild acidosis enhances AMPA receptor-mediated intracellular zinc mobilization in cortical neurons. Mol Med 13:356-361.

Frederickson CJ, Giblin LJ 3rd, Balaji RV, Masalha R, Frederickson CJ, Zeng Y, Lopez EV, Koh JY, Chorin U, Besser L, Hershfinkel M, Li Y, Thompson RB, Krezel A (2006) Synaptic release of zinc from brain slices: factors governing release, imaging, and accurate calculation of concentration. J Neurosci Methods 154:19-29.

Friedlich AL, Lee JY, van Groen T, Cherny RA, Volitakis I, Cole TB, Palmiter
RD, Koh JY, Bush AI (2004) Neuronal zinc exchange with the blood vessel wall promotes cerebral amyloid angiopathy in an animal model of Alzheimer's disease. J Neurosci 24:3453-3459.

Fukahori M, Itoh M (1990) Effects of dietary zinc status on seizure susceptibility and hippocampal zinc content in the El (epilepsy) mouse. Brain Res 529:16-22.

Ganju N, Eastman A (2003) Zinc inhibits Bax and Bak activation and cytochrome $\mathrm{c}$ release induced by chemical inducers of apoptosis but not by death-receptor-initiated pathways. Cell Death Differ 10:652-661.

Gazaryan IG, Krasinskaya IP, Kristal BS, Brown AM (2007) Zinc irreversibly damages major enzymes of energy production and antioxidant defense prior to mitochondrial permeability transition. J Biol Chem 282:24373-24380.

Greenough MA, Volitakis I, Li QX, Laughton K, Evin G, Ho M, Dalziel AH, Camakaris J, Bush AI (2011) Presenilins promote the cellular uptake of copper and zinc and maintain $\mathrm{Cu}$-chaperone of sod1-dependent $\mathrm{Cu} / \mathrm{Zn}$ superoxide dismutase activity. J Biol Chem 286:9776-9786.

Hershfinkel M, Kandler K, Knoch ME, Dagan-Rabin M, Aras MA, Abramovitch-Dahan C, Sekler I, Aizenman E (2009) Intracellular zinc inhibits KCC2 transporter activity. Nat Neurosci 12:725-727.

Huang X, Atwood CS, Moir RD, Hartshorn MA, Vonsattel JP, Tanzi RE, Bush AI (1997) Zinc-induced Alzheimer's Abetal-40 aggregation is mediated by conformational factors. J Biol Chem 272:26464-26470.

Huang YZ, Pan E, Xiong ZQ, McNamara JO (2008) Zinc-mediated transactivation of TrkB potentiates the hippocampal mossy fiber-CA3 pyramid synapse. Neuron 57:546-558.

Hughes FM Jr, Bortner CD, Purdy GD, Cidlowski JA (1997) Intracellular $\mathrm{K}+$ suppresses the activation of apoptosis in lymphocytes. J Biol Chem 272:30567-30576.

Hughes FM Jr, Cidlowski JA (1999) Potassium is a critical regulator of apoptotic enzymes in vitro and in vivo. Adv Enzyme Regul 39:157-171.

Hurst TK, Wang D, Thompson RB, Fierke CA (2010) Carbonic anhydrase II-based metal ion sensing: advances and new perspectives. Biochim Biophys Acta 1804:393-403.

Hwang JJ, Park MH, Choi SY, Koh JY (2005) Activation of the Trk signaling pathway by extracellular zinc: role of metalloproteinases. J Biol Chem 280:11995-12001.

Hwang JJ, Lee SJ, Kim TY, Cho JH, Koh JY (2008) Zinc and 4-hydroxy-2nonenal mediate lysosomal membrane permeabilization induced by $\mathrm{H}_{2} \mathrm{O}_{2}$ in cultured hippocampal neurons. J Neurosci 28:3114-3122.

Jiang D, Sullivan PG, Sensi SL, Steward O, Weiss JH (2001) Zn(2+) induces permeability transition pore opening and release of pro-apoptotic peptides from neuronal mitochondria. J Biol Chem 276:47524-47529.

Jiang LJ, Vasák M, Vallee BL, Maret W (2000) Zinc transfer potentials of the alpha - and beta-clusters of metallothionein are affected by domain interactions in the whole molecule. Proc Natl Acad Sci U S A 97:2503-2508.

Kay AR (2003) Evidence for chelatable zinc in the extracellular space of the hippocampus, but little evidence for synaptic release of Zn. J Neurosci 23:6847-6855.

Kay AR, Tóth K (2008) Is zinc a neuromodulator? Sci Signal 1:re3.

Kiedrowski L (2011) Cytosolic zinc release and clearance in hippocampal neurons exposed to glutamate- the role of $\mathrm{pH}$ and sodium. J Neurochem 117:231-243

Kim YH, Koh JY (2002) The role of NADPH oxidase and neuronal nitric oxide synthase in zinc-induced poly(ADP-ribose) polymerase activation and cell death in cortical culture. Exp Neurol 177:407-418.

Kim YH, Kim EY, Gwag BJ, Sohn S, Koh JY (1999) Zinc-induced cortical neuronal death with features of apoptosis and necrosis: mediation by free radicals. Neuroscience 89:175-182.

Kodirov SA, Takizawa S, Joseph J, Kandel ER, Shumyatsky GP, Bolshakov VY (2006) Synaptically released zinc gates long-term potentiation in fear conditioning pathways. Proc Natl Acad Sci U S A 103:15218-15223.

Koh JY, Suh SW, Gwag BJ, He YY, Hsu CY, Choi DW (1996) The role of zinc in selective neuronal death after transient global cerebral ischemia. Science 272:1013-1016.

Komatsu K, Kikuchi K, Kojima H, Urano Y, Nagano T (2005) Selective zinc sensor molecules with various affinities for $\mathrm{Zn} 2+$, revealing dynamics and regional distribution of synaptically released $\mathrm{Zn} 2+$ in hippocampal slices. J Am Chem Soc 127:10197-10204.

Lannfelt L, Blennow K, Zetterberg H, Batsman S, Ames D, Harrison J, Masters CL, Targum S, Bush AI, Murdoch R, Wilson J, Ritchie CW (2008) Safety, efficacy, and biomarker findings of PBT2 in targeting Abeta as a 
modifying therapy for Alzheimer's disease: a phase IIa, double-blind, randomised, placebo-controlled trial. Lancet Neurol [Erratum (2009) 8:981] 7:779-786.

Lavoie N, Peralta MR 3rd, Chiasson M, Lafortune K, Pellegrini L, Seress L, Tóth K (2007) Extracellular chelation of zinc does not affect hippocampal excitability and seizure-induced cell death in rats. J Physiol 578:275-289.

Lee JM, Kim YJ, Ra H, Kang SJ, Han S, Koh JY, Kim YH (2008) The involvement of caspase-11 in TPEN-induced apoptosis. FEBS Lett 582:1871-1876.

Lee JY, Mook-Jung I, Koh JY (1999) Histochemically reactive zinc in plaques of the Swedish mutant $\beta$-amyloid precursor protein transgenic mice. J Neurosci 19:RC10.

Lee JY, Cole TB, Palmiter RD, Koh JY (2000) Accumulation of zinc in degenerating hippocampal neurons of ZnT3-null mice after seizures: evidence against synaptic vesicle origin. J Neurosci 20:RC79.

Lee JY, Cole TB, Palmiter RD, Suh SW, Koh JY (2002) Contribution by synaptic zinc to the gender-disparate plaque formation in human Swedish mutant APP transgenic mice. Proc Natl Acad Sci U S A 99:7705-7710.

Lee JY, Kim JH, Palmiter RD, Koh JY (2003) Zinc released from metallothionein-iii may contribute to hippocampal CA1 and thalamic neuronal death following acute brain injury. Exp Neurol 184:337-347.

Lee J-Y, Kim J-H, Hong SH, Lee JY, Cherny RA, Bush AI, Palmiter RD, Koh J-Y (2004) Estrogen decreases zinc transporter 3 expression and synaptic vesicle zinc levels in mouse brain. J Biol Chem 279:8602-8607.

Li Y, Hough CJ, Frederickson CJ, Sarvey JM (2001) Induction of mossy fiber $\rightarrow \mathrm{Ca} 3$ long-term potentiation requires translocation of synaptically released $\mathrm{Zn}^{2+}$. J Neurosci 21:8015-8025.

Li Y, Calfa G, Inoue T, Amaral MD, Pozzo-Miller L (2010) Activitydependent release of endogenous BDNF from mossy fibers evokes a TRPC 3 current and $\mathrm{Ca} 2+$ elevations in CA3 pyramidal neurons. J Neurophysiol 103:2846-2856.

Lopantsev V, Wenzel HJ, Cole TB, Palmiter RD, Schwartzkroin PA (2003) Lack of vesicular zinc in mossy fibers does not affect synaptic excitability of CA3 pyramidal cells in zinc transporter 3 knockout mice. Neuroscience 116:237-248.

Lovell MA, Robertson JD, Teesdale WJ, Campbell JL, Markesbery WR (1998) Copper, iron and zinc in Alzheimer's disease senile plaques. J Neurol Sci 158:47-52.

Malaiyandi LM, Dineley KE, Reynolds IJ (2001) Metallothionein overexpression enhances oxidant-induced zinc release in astrocytes. Soc Neurosci Abstr 27:868.816.

Malaiyandi LM, Dineley KE, Reynolds IJ (2004) Divergent consequences arise from metallothionein overexpression in astrocytes: zinc buffering and oxidant-induced zinc release. Glia 45:346-353.

Malaiyandi LM, Honick AS, Rintoul GL, Wang QJ, Reynolds IJ (2005) $\mathrm{Zn}^{2+}$ inhibits mitochondrial movement in neurons by phosphatidylinositol 3-kinase activation. J Neurosci 25:9507-9514.

Martel G, Hevi C, Friebely O, Baybutt T, Shumyatsky GP (2010) Zinc transporter 3 is involved in learned fear and extinction, but not in innate fear. Learn Mem 17:582-590.

Martel G, Hevi C, Kane-Goldsmith N, Shumyatsky GP (2011) Zinc transporter $\mathrm{ZnT} 3$ is involved in memory dependent on the hippocampus and perirhinal cortex. Behav Brain Res 223:233-238.

McLaughlin B, Pal S, Tran MP, Parsons AA, Barone FC, Erhardt JA, Aizenman E (2001) p38 activation is required upstream of potassium current enhancement and caspase cleavage in thiol oxidant-induced neuronal apoptosis. J Neurosci 21:3303-3311.

Medvedeva YV, Lin B, Shuttleworth CW, Weiss JH (2009) Intracellular $\mathrm{Zn}^{2+}$ accumulation contributes to synaptic failure, mitochondrial depolarization, and cell death in an acute slice oxygen-glucose deprivation model of ischemia. J Neurosci 29:1105-1114.

Miller LM, Wang Q, Telivala TP, Smith RJ, Lanzirotti A, Miklossy J (2006) Synchrotron-based infrared and X-ray imaging shows focalized accumulation of $\mathrm{Cu}$ and $\mathrm{Zn}$ co-localized with beta-amyloid deposits in Alzheimer's disease. J Struct Biol 155:30-37.

Molnár P, Nadler JV (2001a) Lack of effect of mossy fiber-released zinc on granule cell GABA-A receptors in the pilocarpine model of epilepsy. J Neurophysiol 85:1932-1940.

Molnár P, Nadler JV (2001b) Synaptically-released zinc inhibits N-methyl$\mathrm{D}$-aspartate receptor activation at recurrent mossy fiber synapses. Brain Res 910:205-207.
Nakashima AS, Dyck RH (2009) Zinc and cortical plasticity. Brain Res Rev 59:347-373.

Noh KM, Kim YH, Koh JY (1999) Mediation by membrane protein kinase C of zinc-induced oxidative neuronal injury in mouse cortical cultures. J Neurochem 72:1609-1616.

Noh KM, Yokota H, Mashiko T, Castillo PE, Zukin RS, Bennett MV (2005) Blockade of calcium-permeable AMPA receptors protects hippocampal neurons against global ischemia-induced death. Proc Natl Acad Sci U S A 102:12230-12235.

Nowak G, Legutko B, Szewczyk B, Papp M, Sanak M, Pilc A (2004) Zinc treatment induces cortical brain-derived neurotrophic factor gene expression. Eur J Pharmacol 492:57-59.

Nozaki C, Vergnano AM, Filliol D, Ouagazzal AM, Le Goff A, Carvalho S, Reiss D, Gaveriaux-Ruff C, Neyton J, Paoletti P, Kieffer BL (2011) Zinc alleviates pain through high-affinity binding to the NMDA receptor NR2A subunit. Nat Neurosci 14:1017-1022.

Pal SK, Takimoto K, Aizenman E, Levitan ES (2006) Apoptotic surface delivery of K+ channels. Cell Death Differ 13:661-667.

Pal S, Hartnett KA, Nerbonne JM, Levitan ES, Aizenman E (2003) Mediation of neuronal apoptosis by Kv2.1-encoded potassium channels. J Neurosci 23:4798-4802.

Pal S, He K, Aizenman E (2004) Nitrosative stress and potassium channelmediated neuronal apoptosis: is zinc the link? Pflugers Arch 448:296-303.

Paoletti P, Ascher P, Neyton J (1997) High-affinity zinc inhibition of NMDA NR1-NR2A receptors. J Neurosci 17:5711-5725.

Paoletti P, Perin-Dureau F, Fayyazuddin A, Le Goff A, Callebaut I, Neyton J (2000) Molecular organization of a zinc binding N-terminal modulatory domain in a NMDA receptor subunit. Neuron 28:911-925.

Paoletti P, Vergnano AM, Barbour B, Casado M (2009) Zinc at glutamatergic synapses. Neuroscience 158:126-136.

Pellegrini-Giampietro DE, Gorter JA, Bennett MV, Zukin RS (1997) The GluR2 (GluR-B) hypothesis: $\mathrm{Ca}(2+)$-permeable AMPA receptors in neurological disorders. Trends Neurosci 20:464-470.

Qian J, Noebels JL (2005) Visualization of transmitter release with zinc fluorescence detection at the mouse hippocampal mossy fibre synapse. J Physiol 566:747-758.

Qin Y, Dittmer PJ, Park JG, Jansen KB, Palmer AE (2011) Measuring steadystate and dynamic endoplasmic reticulum and Golgi $\mathrm{Zn} 2+$ with genetically encoded sensors. Proc Natl Acad Sci U S A 108:7351-7356.

Rachline J, Perin-Dureau F, Le Goff A, Neyton J, Paoletti P (2005) The micromolar zinc-binding domain on the NMDA receptor subunit NR2B. J Neurosci 25:308-317.

Redman PT, Jefferson BS, Ziegler CB, Mortensen OV, Torres GE, Levitan ES, Aizenman E (2006) A vital role for voltage-dependent potassium channels in dopamine transporter-mediated 6-hydroxydopamine neurotoxicity. Neuroscience 143:1-6.

Redman PT, He K, Hartnett KA, Jefferson BS, Hu L, Rosenberg PA, Levitan ES, Aizenman E (2007) Apoptotic surge of potassium currents is mediated by p38 phosphorylation of Kv2.1. Proc Natl Acad Sci U S A 104:3568-3573

Redman PT, Hartnett KA, Aras MA, Levitan ES, Aizenman E (2009) Regulation of apoptotic potassium currents by coordinated zinc-dependent signalling. J Physiol 587:4393-4404.

Religa D, Strozyk D, Cherny RA, Volitakis I, Haroutunian V, Winblad B, Naslund J, Bush AI (2006) Elevated cortical zinc in Alzheimer disease. Neurology 67:69-75.

Ruiz A, Walker MC, Fabian-Fine R, Kullmann DM (2004) Endogenous zinc inhibits GABA(A) receptors in a hippocampal pathway. J Neurophysiol 91:1091-1096.

Sensi SL, Yin HZ, Carriedo SG, Rao SS, Weiss JH (1999) Preferential Zn2+ influx through $\mathrm{Ca} 2+$-permeable AMPA/kainate channels triggers prolonged mitochondrial superoxide production. Proc Natl Acad Sci U S A 96:2414-2419.

Sensi SL, Yin HZ, Weiss JH (2000) AMPA/kainate receptor-triggered Zn2+ entry into cortical neurons induces mitochondrial $\mathrm{Zn} 2+$ uptake and persistent mitochondrial dysfunction. Eur J Neurosci 12:3813-3818.

Sensi SL, Ton-That D, Sullivan PG, Jonas EA, Gee KR, Kaczmarek LK, Weiss $\mathrm{JH}$ (2003) Modulation of mitochondrial function by endogenous $\mathrm{Zn} 2+$ pools. Proc Natl Acad Sci U S A 100:6157-6162.

Sensi SL, Paoletti P, Bush AI, Sekler I (2009) Zinc in the physiology and pathology of the CNS. Nat Rev Neurosci 10:780-791. 
Sheline CT, Behrens MM, Choi DW (2000) Zinc-induced cortical neuronal death: contribution of energy failure attributable to loss of $\mathrm{NAD}(+)$ and inhibition of glycolysis. J Neurosci 20:3139-3146.

Sindreu C, Palmiter RD, Storm DR (2011) Zinc transporter ZnT-3 regulates presynaptic Erk1/2 signaling and hippocampus-dependent memory. Proc Natl Acad Sci U S A 108:3366-3370.

Smith RD, Goldin AL (1997) Phosphorylation at a single site in the rat brain sodium channel is necessary and sufficient for current reduction by protein kinase A. J-Neurosci 17:6086-6093.

Stork CJ, Li YV (2006) Intracellular zinc elevation measured with a "calcium-specific" indicator during ischemia and reperfusion in rat hippocampus: a question on calcium overload. J Neurosci 26:1043010437.

Tønder N, Johansen FF, Frederickson CJ, Zimmer J, Diemer NH (1990) Possible role of zinc in the selective degeneration of dentate hilar neurons after cerebral ischemia in the adult rat. Neurosci Lett 109:247-252.

Traynelis SF, Burgess MF, Zheng F, Lyuboslavsky P, Powers JL (1998) Control of voltage-independent zinc inhibition of NMDA receptors by the NR1 subunit. J Neurosci 18:6163-6175.
Vincent AM, Maiese K (1999) Nitric oxide induction of neuronal endonuclease activity in programmed cell death. Exp Cell Res 246:290-300.

Vincent AM, TenBroeke M, Maiese K (1999) Neuronal intracellular pH directly mediates nitric oxide-induced programmed cell death. J Neurobiol 40:171-184.

Vogt K, Mellor J, Tong G, Nicoll R (2000) The actions of synaptically released zinc at hippocampal mossy fiber synapses. Neuron 26:187-196.

Wang T, Zheng W, Xu H, Zhou JM, Wang ZY (2010) Clioquinol inhibits zinc-triggered caspase activation in the hippocampal CA1 region of a global ischemic gerbil model. PLoS One 5:e11888.

Yang Y, Kawataki T, Fukui K, Koike T (2007) Cellular Zn2 + chelators cause "dying-back" neurite degeneration associated with energy impairment. J Neurosci Res 85:2844-2855.

Yin HZ, Sensi SL, Ogoshi F, Weiss JH (2002) Blockade of $\mathrm{Ca}^{2+}$-permeable AMPA/kainate channels decreases oxygen-glucose deprivation-induced $\mathrm{Zn}^{2+}$ accumulation and neuronal loss in hippocampal pyramidal neurons. J Neurosci 22:1273-1279.

Yu SP, Yeh CH, Sensi SL, Gwag BJ, Canzoniero LM, Farhangrazi ZS, Ying HS, Tian M, Dugan LL, Choi DW (1997) Mediation of neuronal apoptosis by enhancement of outward potassium current. Science 278:114-117. 